\title{
ПСИХОЛОГІЧНІ МАРКЕРИ РЕЛІГІЙНИХ НОВИН ЯК ФОРМИ МАСОВОЇ КОМУНІКАЦІї
}

\author{
Коструба Наталія \\ Волинський національний університет імені Лесі Українки, \\ м. Луцьк, Україна, \\ chmil.nata@ukr.net \\ https://orcid.org/0000-0002-3852-4729
}

\begin{abstract}
Mema. Мета статті - емпірично визначити основні психологічні маркери релігійних новин.
\end{abstract}

Memodu. Для реалізації мети дослідження використано комп'ютерне забезпечення Statistica 12 та Linguistic Inquiry and Word Count (LIWC2015). Матеріалом для дослідження обрано новини найчисельніших церков в Україні (православні, католики, протестанти). Для аналізу застосовано всі інформаційні повідомлення за період із 27.11. по 03.12. 2020 р., розміщені на офіційних інтернет-сайтах. Загалом проаналізовано 43 інформаційні повідомлення.

Результати. Серед усіх категорій стильових слів в опрацьованих повідомленнях домінують прийменники, сполучники й займенники. Аналіз змістовного наповнення релігійних новин продемонстрував, що найбільше текст стосується просторових зв'язків (7,03 \%), мотиваторів (drivers), які спонукають до дій $(5,99 \%)$, когнітивних процесів $(4,74 \%)$, соціуму та соціальних процесів $(2,96 \%)$, приналежності $(2,17 \%)$, релігійна термінологія $(2,08 \%)$. Оцінка частотності використання слів у релігійних новинах виявила, що найчастіше використовуються слова «українське», «церква», «храм». Змістовно новини часто стосуються відзначення знаменних дат чи вшанування пам'яті тощо. Це підтверджує часте вживання слів «року» й «свят». Загалом, релігійні повідомлення закликають до єдності, постійно використовуючи слова «наш», «наше», за їх допомогою намагаються згуртувати наш народ навколо української ідентичності. Також часто в релігійних новинах використовують слова «орган» $\mathrm{i}$ «представник». Тут ідеться про уповноважені органи влади.

Висновки. Релігійні новини виконують просвітницьку діяльність і соціальну рекламу єдності та взаємопідтримки не лише на основі спільної віри, але й однієї нації й подолання складних часів для всієї аудиторії (як-от пандемія Covid-19). Релігійні новини апелюють не лише до віри, але й до розуму своєї аудиторії, про що свідчить когнітивна складність тексту. Повідомлення спрямовані на оцінку та обговорення сьогодення без прогнозів на майбутнє. Наскрізною характеристикою всіх повідомлень $є$ звернення до церковної замученості за посередництва закликів до молитов i читання релігійної літератури. У сучасних релігійних новинах часто згадуються органи державної влади, наголошується на їх авторитетності.

ISSN 2308-3743 (Online), ISSN 2227-1376 (Print)

(C) Коструба Н., 2020. Ця стаття відкритого доступу на умовах CC BY-NC 4.0 
Ключові слова: релігія онлайн, релігійні комунікації, психолінгвістика, психологія новин, LIWC2015.

Natalia Kostruba. Religious News as a Form of Mass Communication: Psychological Markers. Purpose. The purpose of the article is to empirically determine the main psychological markers of religious news.

Methods. To achieve the goal of the study, we used computer software Statistica 12 and Linguistic Inquiry and Word Count (LIWC2015). Research materials were news of the largest churches in Ukraine (Orthodox, Catholic, Protestant). All information messages for the period from 27.11.-03.12.2020. In total, 43 information messages were analyzed.

Results. Prepositions, conjunctions and pronouns dominate among all categories of stylistic words. The analysis of religious news showed that most of the text concerns spatial connections $(7,03 \%)$, motivators (drivers) that motivate actions $(5,99 \%)$, cognitive processes $(4,74 \%)$, society and social processes (2,96\%), affiliation $(2,17 \%)$, religious terminology $(2,08 \%)$. The words «Ukrainian», «church», «temple» are most often used in religious news. The content of the news is often about celebrating significant dates or commemorating, and so on. This fact confirms the frequent use of the words «year» and «holidays». In general, religious messages call for unity, using the words «ours» and trying to unite people around Ukrainian identity. The words «authority» and «representative2 are often used in religious news.

Conclusions. Religious news carries out educational activities and social advertising of unity and mutual support. The unifying factors are not only the common faith, but also one nation and overcoming difficult times for the whole audience (in particular, the Covid-19 pandemic). Religious news has a great cognitive complexity of the text. Messages evaluate and discuss the present, no predictions for the future. A cross-cutting feature of all messages is the appeal to church involvement, calls to prayer and reading of religious literature. Modern religious news often mentions public authorities, emphasizing their authority.

Key words: online religion, religious communications, psycholinguistics, psychology of news, LIWC 2015.

Коструба Наталья. Психологические маркеры религиозных новостей как формы массовой коммуникации. Цель. Цель статьи - эмпирическое изучение основных психологических маркеров религиозных новостей.

Memoдbl. Для реализации цели исследования мы использовали компьютерное обеспечение Statistica 12 и Linguistic Inquiry and Word Count (LIWC2015). Материалом для исследования выбрали новости многочисленных церквей в Украине (православные, католики, протестанты). Для анализа использовались все информационные сообщения за период с 27.11. по 03.12. 2020 г., которые были размещены на официальных интернет-сайтах. Всего анализируется 43 информационные сообщения.

Pезультаты. Среди всех категорий стилевых слов в обработанных сообщениях доминируют предлоги, союзы и местоимения. Анализ содержательного 
наполнения религиозных новостей продемонстрировал, что больше всего текст касается пространственных связей (7,03 \%), мотиваторов (drivers), которые побуждают к действиям (5,99\%), когнитивных процессов $(4,74 \%)$, социума и социальных процессов $(2,96 \%)$, принадлежности $(2,17 \%)$, религиозной терминологии $(2,08 \%)$. Оценка частоты использования слов в религиозных новостях подтвердила, что наиболее часто используются слова «украинское», «церковь», «храм». Содержательно новости часто касаются празднования знаменательных дат или памяти. Это подтверждает частое использование слов «года» и «праздников». Религиозные сообщение призывают к единству, постоянно используя слова «наш», «наше» и пытается сплотить наш народ вокруг украинской идентичности. Также часто в религиозных новостях используют слова «орган» и «представитель», здесь речь идет о компетентных органах.

Bblвodbl. Религиозные новости осуществляют просветительскую деятельность и социальную рекламу единства и взаимной поддержки на основе не только общей веры, но и одной нации и преодоления сложных времен для всей аудитории (например пандемии Covid-19). Религиозные новости апеллируют не только к вере, но и к разуму своей аудитории, о чем свидетельствует когнитивная сложность текста. Сообщение направленные на оценку и обсуждение настоящего без прогнозов на будущее. Сквозной характеристикой сообщений является их обращение к церковной вовлеченности, призыв к молитвам и чтению религиозной литературы. Современные религиозные новости часто вспоминают органы государственной власти, отмечают их авторитетность.

Ключевые слова: религия онлайн, религиозные коммуникации, психолингвистика, психология новостей, LIWC 2015.

Вступ. Сучасні комунікації у всіх сферах життєдіяльності все частіше реалізовуються онлайн, що забезпечує поширення інформаційних повідомлень серед широкої маси людей. Такі тенденції проявляються і в релігійній сфері. Для привернення уваги молоді церкви все частіше використовують сайти, соціальні мережі та мобільні додатки.

Релігійні новини вже давно є складовою частиною пересічного інформаційного огляду дня. Часто релігійні ЗМІ поширюють новини не лише культово-обрядового чи світоглядного змісту, а й дають оцінку державним, військовим чи політичним подіям. Загалом під релігійними новинами можна вважати всі новини, які мають своїм предметом огляд релігійного кола питань. Або ж новини від релігійних інституцій, котрі крізь призму свого світогляду розглядають усі події країни та світу. Дослідження релігійних новин, їхньої специфіки, змісту й впливу на громадську думку проводяться науковцями у всьому світі (Carignan, Marcil-Morin, 2018; Hart, Turner, Knupp, 1981; Mostafazadeh-Bora, Zarghami, 2017). 
Вивчення релігійних новин часто здійснюється в певному контексті. Так, існують дослідження того, як відбувається висвітлення релігійної приналежності біженців $\mathrm{i}$, отже, формування певного ставлення в глядачів телевізійних новин (Nassar, 2020). Про розкриття в новинах різних релігійних напрямів і їхніх представників, поділ їх на «хороші» та «погані» говорять R. A. Thomson, J. Z. Park, D. Kendall (Thomson, Park, Kendall, 2019).

Один із напрямів дослідження зосереджується на тому, як сприйняття релігійних новин залежить від когнітивних стилів. Загалом науковці припускають, що аналітичне мислення має тенденцію послаблювати релігійну віру (Gervais, Norenzayan, 2012). Sara Savage 3 колегами емпірично виявили, що в релігійному пізнанні люди використовують когнітивну простоту, а не складні мисленнєві процеси (Savage, 2013). Цей факт може частково пояснити результати дослідження щодо сприймання фейкових новин, отримані групою вчених на чолі з M. V. Bronstein. Виявлено, що релігійні особистості частіше схильні вірити фейковим новинам (Bronstein, Pennycook, Bear, Rand, Cannon, 2019).

Про тісний зв'язок між релігійними й політичними міркуваннями в ЗМІ стверджують учені на чолі з M. Hinrichsen, аналізуючи вміст обсягу релігійних новин у висвітленні ЄС у німецьких та голландських газетах (Hinrichsen, Boomgaarden, De Vreese, Van der Brug, Hobolt, 2012). Особливості подання однієї й тієї самої події в загальнопопулярних, політичних і релігійних виданнях розкрито в працях J. Y. Abbott (Abbott, 2011). На основі результатів роботи дослідниця аналізує журналістські формати висвітлення новин у різних сферах і виданнях.

Мета дослідження - емпірично визначити основні психологічні маркери релігійних новин.

Методи та процедура дослідження. Для реалізації мети дослідження використано комп'ютерне забезпечення Statistica 12 та Linguistic Inquiry and Word Count (LIWC) (Pennebaker, Boyd, Jordan, Blackburn, 2015). Програма LIWC є ефективним методом вивчення емоційних, когнітивних i структурних компонентів, що наявні у вербальних та письмових зразках мовлення людей. Програма активно використовується науковцями для прикладних досліджень (Pennebaker, Chung, Frazee, Lavergne, Beaver, 2014). LIWC містить два блоки - програмне забезпечення та словники. Убудовані в програму відразу англійський і німецький словники. Український словник до програми 
розробив С. В. Засєкін (Zasiekin, Bezuglova, Hapon, Matiushenko, Podolska, Zubchuk, 2018).

LIWC дає змогу отримати понад 80 показників за лінгвістичними, психологічними, граматичними шкалами. Ми у своїй роботі розглянемо психологічні й лінгвістичні показники. Більшість змінних LIWC2015 виражаються у відсотках від загальної кількості слів.

Матеріалом для дослідження обрано новини найчисленніших церков в Україні (православні, католики, протестанти). Інформація щодо кількості релігійних організацій грунтується на даних Департаменту у справах релігій та національностей Міністерства культури України (Report, 2019). Для аналізу використано всі інформаційні повідомлення за період із 27.11. до 03.12. 2020 р., які були розміщені на офіційних інтернет-сайтах Православної церкви України (ПЦУ, pomisna.info), Української православної церкви Московського патріархату (УПЦ МП, news.church.ua), Української греко-католицької церкви (УГКЦ, ugcc.ua) та Протестантської церкви України (протестанти, baptyst.com). В усіх заявлених церквах наявні прес-служби й офіційні очільники, окрім протестантизму, який представлений безліччю конфесій. Ми розглядаємо звернення Ради Євангельських протестантських церков України, яка $є$ координаційним органом таких церков. Загалом, проаналізовано 43 інформаційні повідомлення.

Обговорення результатів. Загалом усі опрацьовані новини становили 18367 слів, середня довжина речення - 19,71 слів. Український словник у програмі LIWC2015 розпізнав 98,17 \% від усього тексту.

Наше дослідження грунтується на думках Y. R. Tausczik та J. W. Pennebaker про існування широких категорій слів, які мають різні психометричні та психологічні властивості: змістовні (іменники, регулярні дієслова, прикметники й прислівники) і стильові чи функціональні (займенники, прийменники, сполучники, допоміжні дієслова). Автори стверджують, що функціональні слова, зазвичай, є більш надійними маркерами психологічних станів, ніж змістовні (Tausczik, Pennebaker, 2010). У табл. 1 представлено результати аналізу стильових слів.

Серед усіх категорій стильових слів в опрацьованих повідомленнях домінують прийменники, сполучники та займенники. Найбільш численними серед займенників є безособові (2,47 \%), які представлені в тексті: iнші, u̧i, mux, ycix, кожного. В опрацьованих релігійних 
повідомленнях виявлено достатньо високі відсотки вживання прийменників $(8,59 \%)$ і сполучників (5,7 \%), що свідчить про когнітивну складність (Pennebaker, King, 1999). Такі дані підтверджують, що релігійні новини за своїми стильовими особливостями є доказовими, тобто в тексті зазначається багато фактів, попередніх подій тощо. Також аналіз стильових маркерів опрацьованих повідомлень дав змогу виявити незначні прояви емоційної напруги, що підтверджується частим використанням запитальних слів $(1,84$ \%) i заперечень $(0,93 \%)$.

Табличя 1

\section{Стильові показники релігійних новин}

\begin{tabular}{|l|c|}
\hline & $\begin{array}{c}\text { General indicators, } \\
\%\end{array}$ \\
\hline Total function words & 19,95 \\
\hline Total pronouns & 5,28 \\
\hline Personal pronouns & 1,19 \\
\hline 1st pers singular & 0,16 \\
\hline 1st pers plural & 0,51 \\
\hline 2nd person & 0,17 \\
\hline 3rd pers singular & 0,19 \\
\hline 3rd pers plural & 0,16 \\
\hline Impersonal pronouns & 2,47 \\
\hline Prepositions & 8,59 \\
\hline Auxiliary verbs & 0,55 \\
\hline Common Adverbs & 1,04 \\
\hline Conjunctions & 5,70 \\
\hline Negations & 0,93 \\
\hline
\end{tabular}

Наступним етапом аналізу релігійних новин стала оцінка їх змістовного наповнення. Загалом 77,76 \% 3 усіх опрацьованих слів потрапили до категорії відносності, тобто їх змістовне наповнення залежить від контексту. Також ця категорія демонструє те, на чому акцентовано увагу, на пов'язаності рухом, часом чи простором. Так, у релігійних новинах часто йдеться про просторовий зв'язок (7,03 \%), що проявляється в словах народ, громада, національний тощо. Також достатньо часто в повідомленнях ідеться про те, що всі ми проживаємо в один час i, отже, пов'язані (2,49 \%). Такі результати демонструють, що релігійні новини реалізовують просвітницьку діяльність й соціальну рекламу єдності та взаємопідтримки не лише на основі спільної 
віри, але й однієї країни й однаково складні часи для всієї аудиторії (як-от пандемія Covid-19).

Порівняно часто в релігійних новинах згадуються про соціум та соціальні процеси (2,96 \%). Серед слів цієї категорії трапляються акценти на громаду, народ, братів та сестер. Підкреслення соціальних зав'язків найчастіше стосується сім'ї (0,57\%), що, імовірно, означає традиційне релігійне звертання «дорогі брати та сестри». Емоційних слів у релігійних новинах виявлено не багато - 1,37\%, більшість із них мають позитивне емоційне спрямування (0,92\%). У межах цієї категорії найчастіше трапляються слова спільний, безпека, віра, надія, допомога, створення тощо.

Багато слів в опрацьованих повідомленнях стосуються когнітивних процесів (4,74 \%), а найбільша кількість слів цієї тематичної групи - розрізнення $(1,77 \%)$, серед яких - різних, інших, відзнак. Також часто бувають слова, що вказують на причинно-наслідкові зв'язки $(1,16 \%)$, а саме: так...як, бо, адже. Багато слів, які вказують на когнітивні процеси, демонструють, що релігійні новини апелюють не лише до віри, але й до розуму своєї аудиторії.

Численною виявилася категорія слів - мотиваторів, тобто тих, що спонукають до дій (5,99 \%). Найбільше лексем цієї тематичної групи стосуються приналежності (2,17 \%), а саме спільнота, член, храм, церква. Також серед мотиваторів часто використовуються слова влади $(1,01 \%)$, серед яких - керівництво, влада, президент, міліонери тощо. Так, релігійні новини очікувано опираються на приналежність до однієї релігійної спільноти й часто на цьому наголошують. Проте отримані результати порівняно частих згадок влади демонструють тісний взаємозв’язок релігії та політики в нашій країні.

Проаналізувавши часову перспективу опрацьованих релігійних новин, ми виявили, що найчастіше вони описують сучасні події $(1,03 \%)$, а також опираються на минуле $(0,71 \%)$. Дуже рідко в релігійних повідомленнях обговорюють майбутнє (0,26 \%).

Щодо змістового наповнення інформаційних повідомлень, то багато слів свідчать про релігійне наповнення новин (2,08 \%). До цієї категорії належить специфічна релігійна термінологія, як-от: євангельський, протестантський, проповідник, Богородиия, Христос, катедральний храм тощо. Крім того, багато слів стосуються роботи (1,15\%), а саме: організовувати, працювати, обов'язки тощо. Отже, у релігій- 
них новинах звітують про активну діяльність церков, а також пропагують активну діяльність активістів і волонтерів.

За допомогою функції Text Mining у програмі Statistica 12 виявлено найчастотніші слова в опрацьованих 43 повідомленнях. Частоту вживання лексем перевіряли за коренем слова, тобто слова розглядали без закінчень. Ці дані представлено в табл. 2.

Таблиия 2

\section{Найчастотніші слова в релігійних новинах}

\begin{tabular}{|c|c|c|}
\hline & Слово & Кількість повторів \\
\hline 1 & укр & 185 \\
\hline 2 & церкв & 114 \\
\hline 3 & храм & 112 \\
\hline 4 & року & 78 \\
\hline 5 & свят & 68 \\
\hline 6 & єпископ & 59 \\
\hline 7 & православн & 56 \\
\hline 8 & орган & 53 \\
\hline 9 & митропол & 51 \\
\hline 10 & наш & 50 \\
\hline 11 & божу & 48 \\
\hline 12 & життя & 44 \\
\hline 13 & владик & 43 \\
\hline 14 & нову & 41 \\
\hline 15 & люд & 40 \\
\hline 16 & питан & 35 \\
\hline 17 & представник & 31 \\
\hline 18 & священник & 31 \\
\hline
\end{tabular}

Найчастіше в релігійних новинах наголошено на національній приналежності, а також уживають слово «українське». Змістовно це стосується відзначення знаменних дат чи вшанування пам'яті тощо, що підтверджує часте використання слів «року» й «свят». Такі результати свідчать, що релігія закликає до єдності, постійно використовуючи слова «наш», «наше», і намагається згуртувати наш народ навколо української ідентичності. Традиційно достатньо поширеною $є$ релігійна термінологія («церква», «храм», «єпископ», «священник» тощо). Проте часто в релігійних новинах використовують слова «орган» та «представник», тут ідеться про уповноважені органи влади. 
Так, простежено чітку підтримку релігійними інституціями держави та іiі представників.

Достатньо часто в релігійних новинах розповідають про повсякденне життя й сучасні зміни у зв'язку з пандемією, використовуючи слова «життя», «нову» тощо. Описують нову реальність, коли релігія стає частиною віртуального світу. На підтвердження цього деякі новини мають заголовок і короткий опис події з прикріпленим відео 3 виступами й промовами. Цікавий, на наш погляд, виявлений результат щодо частого повторення слова «питання». Так, релігія, яка зазвичай знає відповіді на більшість запитань, покладаючись на віру в Бога та його слово, у сучасному світі ставить запитання для роздумів для своєї аудиторії.

Висновки та перспективи. Сучасні релігійні новини є потужним засобом масової комунікації. Психологічний аналіз релігійних новин за тиждень дав можливість виокремити основні маркери. Загалом, релігійні новини володіють високою когнітивною складністю, про що свідчать і стильові, і змістовні показники. Такі новини часто описують, а також дають оцінку різним подіям із наведенням фактів, аргументацією та поясненнями. Змістовний аналіз інформаційних повідомлень демонструє акценти таких новин на єдності, на спільності простору (одна земля, один народ), приналежності до однієї спільноти, яка поєднана не лише вірою, але й національною ідеєю. Це підтверджує також статистичний аналіз частотності використання слів: слово «українське» трапляється в релігійних новинах найбільше, порівняно із іншими.

Сучасні релігійні новини часто згадують органи державної влади, наголошують на їхній авторитетності. Це підтвердили й результати, отримані за допомогою програми (у категорії мотиватори (drivers), крім афіляції, простежуємо часте звертання до влади) та аналізу частотного застосування слів (часте використання «представник», «орган» тощо). Такі дані демонструють, що релігія й політика в нашій країні пов'язані, підтримують одне одного.

Загалом, текст насичений неозначеними займенниками для привернення уваги, що всі описані події стосуються всіх і кожного. Повідомлення спрямовані на оцінку та обговорення сьогодення, без прогнозів на майбутнє. Наскрізною характеристикою всіх повідомлень $є$ зверненням до церковної залученості, закликами до молитов і читання релігійної літератури, а також зверненням до авторитетності влади. 


\section{Література}

1. Abbott, J. Y. (2011). Writing the news: A comparison of objective, religious, and political opinion presses. Journalism, 12 (3), 349-365. DOI: https://doi.org/10.11 77/1464884910388222

2. Bronstein, M. V., Pennycook, G., Bear, A., Rand, D. G., Cannon, T. D. (2019). Belief in Fake News is Associated with Delusionality, Dogmatism, Religious Fundamentalism, and Reduced Analytic Thinking. Journal of applied research in memory and cognition, 8 (1), 108-117. DOI: https://doi.org/10.1016/j.jarmac. 2018.09.005

3. Carignan, M. E., Marcil-Morin, S. (2018). Canada Transmediality as News Media and Religious Radicalization. Global convergence cultures: transmedia earth, (121-139). Routledge Advances in Internationalizing Media Studies.

4. Gervais, W. M., Norenzayan A. (2012). Analytic Thinking Promotes Religious Disbelief. Science, 336 (6080), 493-496. DOI: https://doi.org/10.1126/ science. 1215647

5. Hart, R. P., Turner, K. J., Knupp, R. E. (1981). A rhetorical profile of religious news-time, 1947-1976. Journal of communication, 31 (3), 58-68. DOI: https://doi.org/10.1111/j.1460-2466.1981.tb00428.x

6. Hinrichsen, M., Boomgaarden, H., De Vreese, C., Van der Brug, W., Hobolt, S. B. (2012). Priming religion: The effects of religious issues in the news coverage on public attitudes towards European integration. Communications-european journal of communication research, 37 (1), 29-54. DOI: https://doi.org/10.1515/commun-20120002

7. Nassar, R. (2020). Framing Refugees: The Impact of Religious Frames on US Partisans and Consumers of Cable News Media. Political communication, 37(5), 593611. DOI: https://doi.org/10.1080/10584609.2020.1723753

8. Mostafazadeh-Bora, M., Zarghami, A. (2017). Breaking and Sharing Bad News in End of Life: The Religious and Culture Matters. Journal of religion \& health, 56 (5), 1655-1657. DOI: https://doi.org/10.1007/s10943-016-0249-0

9. Pennebaker, J. W., Boyd, R. L., Jordan, K., \& Blackburn, K. (2015). The development and psychometric properties of LIWC2015. Austin, TX: University of Texas at Austin.

10. Pennebaker, J. W., \& King, L. A. (1999). Linguistic styles: Language use as an individual difference. Journal of Personality and Social Psychology, 77(6), 12961312. https://doi.org/10.1037/0022-3514.77.6.1296

11. Pennebaker, J. W., Chung, C. K., Frazee, J., Lavergne, G. M., Beaver, D. I. (2014). When Small Words Foretell Academic Success: The Case of College Admissions Essays. PLoS ONE, 9(12): e115844. DOI: https://doi.org/10.1371/ journal.pone. 0115844

12. Report on the network of religious organizations in Ukraine as of January 1, 2019. URL: https://risu.org.ua/ua/index/resourses/statistics/ukr_2019/75410/

13. Savage, S. B. (2013). Head and heart in preventing religious radicalization. In Head and Heart: Perspectives from Religion and Psychology/F. Watts, G. Dumbreck (eds.), 157-194. Philadelphia: Templeton Foundation Press. 
14. Tausczik, Y. R., \& Pennebaker, J. W. (2010). The Psychological Meaning of Words: LIWC and Computerized Text Analysis Methods. Journal of Language and Social Psychology, 29(1), 24-54. https://doi.org/10.1177/0261927X09351676

15. Thomson, R. A. Park, J. Z. Kendall, D. (2019). Religious Conservatives and TV News: Are They More Likely to be Religiously Offended? Social problems, 66(4), 626-644. DOI: https://doi.org/10.1093/socpro/spy024

16. Zasiekin, S., Bezuglova, N., Hapon, A., Matiushenko, V., Podolska, O., \& Zubchuk, D. (2018). Psycholinguistic Aspects of Translating LIWC Dictionary. East European Journal of Psycholinguistics, 5(1), 111-118. DOI: https://doi.org/10.5281/ zenodo. 1436335

Received: 05.09.2020

Accepted: 29.09.2020 